\title{
Epigenetic control of meiotic recombination in plants
}

\author{
YELINA Natasha, DIAZ Patrick, LAMBING Christophe \& HENDERSON Ian R.* \\ Department of Plant Sciences, University of Cambridge, Cambridge, CB2 3EA, UK
}

Received September 1, 2014; accepted December 3, 2014; published online February 4, 2015

\begin{abstract}
Meiotic recombination is a deeply conserved process within eukaryotes that has a profound effect on patterns of natural genetic variation. During meiosis homologous chromosomes pair and undergo DNA double strand breaks generated by the Spo11 endonuclease. These breaks can be repaired as crossovers that result in reciprocal exchange between chromosomes. The frequency of recombination along chromosomes is highly variable, for example, crossovers are rarely observed in heterochromatin and the centromeric regions. Recent work in plants has shown that crossover hotspots occur in gene promoters and are associated with specific chromatin modifications, including H2A.Z. Meiotic chromosomes are also organized in loop-base arrays connected to an underlying chromosome axis, which likely interacts with chromatin to organize patterns of recombination. Therefore, epigenetic information exerts a major influence on patterns of meiotic recombination along chromosomes, genetic variation within populations and evolution of plant genomes.
\end{abstract}

meiosis, recombination, epigenetic, crossover, chromatin

Citation: Yelina N, Diaz P, Lambing C, Henderson IR. Epigenetic control of meiotic recombination in plants. Sci China Life Sci, 2015, 58: 223-231, doi: 10.1007/s11427-015-4811-x

Meiosis is thought to have evolved in an ancestor of eukaryotes and has been maintained in the majority of plant, fungal and animal lineages [1-3]. During meiosis a single round of DNA replication is followed by two rounds of chromosome segregation, which generates recombined haploid gametes that can participate in fertilization [1]. Meiosis is also distinguished from mitosis as during the first division homologous chromosomes become physically paired and undergo recombination, including reciprocal genetic exchange termed crossover [1]. The combination of crossovers, independent chromosome segregation and gamete fusion mean that sexual reproduction generates increased genetic diversity between individuals, relative to asexual reproduction [4]. The precise advantage that sexual reproduction confers is debated, though its advantages must be strong and general as it is maintained in unicellular and multicellular species of variable population sizes and ecolo-

*Corresponding author (email: irh25@cam.ac.uk) gies [4,5]. It is also important to understand meiotic recombination in the context of agricultural breeding, where homologous recombination can be restricted to specific chromosomal regions and thereby limit use of crop genetic variability [6].

\section{Meiotic recombination between homologous chromosomes}

Meiotic recombination is initiated by programmed DNA double-strand breaks (DSBs), catalyzed by the conserved topoisomerase-like transesterase SPO11 [7,8]. SPO11 becomes covalently bound to DNA via a phosphodiester bond between the DSB 5'-end and a catalytic tyrosine residue $[9,10]$. Following DSB formation the DNA is nicked in an adjacent region by Mre11/Sae2 and DSB $5^{\prime}$-ends are further resected by the $5^{\prime}-3^{\prime}$ and $3^{\prime}-5^{\prime}$ exonuclease activities of Exo1 and Mre11 respectively, yielding $3^{\prime}$-tails of single 
stranded DNA (ssDNA) 1-2 kb in length [10,11]. Meiotic ssDNA is bound by the RecA-related Rad51 and Dmc1 recombinases, which direct homology search, invasion of the ssDNA 3'-end and base-pairing with the homologous chromosome $[12,13]$. Formation of a heteroduplex DNA molecule displaces the non-complementary strand of the homologue forming a displacement loop (D-loop). In budding yeast, plants and mice formation of DSBs by Spo11 and recombination are necessary for pairing of chromosomes [1]. For example, Arabidopsis spol1-1 mutants show 10 univalents at metaphase-I instead of five paired bivalents and both spol1-1 and $d m c 1$ mutants fail to synapse $[14,15]$. Following strand invasion the heteroduplex intermediate can enter different DNA repair pathways [16]. D-loops are relatively unstable molecules and can be dissociated after short extension of the ssDNA 3 '-end by DNA synthesis, re-associate with the parental duplex and are repaired via synthesis-dependent strand annealing (SDSA) to form a non-crossover [17]. Alternatively, D-loops can be stabilized and ssDNA 3 '-ends elongated further by DNA synthesis using the complementary strand of the homologous chromosome as a template. Finally, second-end capture results in the formation of a double Holliday junction $(\mathrm{dHj})$, which can be resolved to form a non-crossover or a crossover $[17,18]$ (Figure 1). In plants and mammals, such as mice, a greater number of meiotic DSBs form than mature into crossovers. In Arabidopsis it is estimated that 200 DSBs are generated per nucleus, with only $\sim 10$ maturing into crossovers [19-22] (Figure 1). The remaining DSBs are thought to be repaired as non-crossovers or via inter-sister

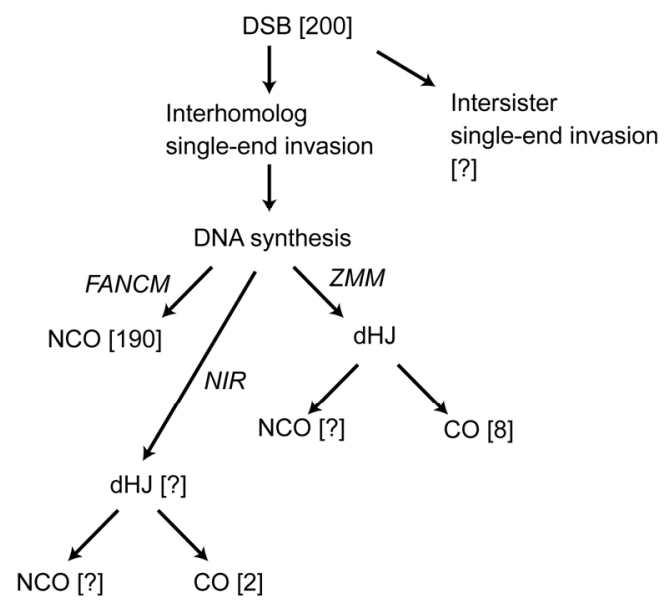

Figure 1 Genetic model for control of meiotic recombination in Arabidopsis. The branching diagram represents a genetic model for control of meiotic recombination in Arabidopsis. Approximately 200 DNA double strand breaks (DSBs) are formed per meiosis, with an unknown number of DSBs repaired via intersister recombination. The remaining DSBs then mature into interhomolog strand invasion events. The majority of strand invasion events are repaired as non-crossovers (NCOs) via FANCM. The 'ZMM' pathway forms crossovers via double Holliday junctions $(\mathrm{dHjs})$ that are subject to interference. A minority of crossovers are generated via a non-interfering pathway $(N I R)$. The estimated number of recombination events shown in parentheses are based on published observations [20,21,45,60,139-142]. repair (Figure 1).

In plants the majority of crossovers are formed via the interfering pathway, also known as the ZMM pathway [23] (Figure 1). Crossover interference is defined by the observation that crossovers are often more widely distributed than expected at random [24-26]. A large number of proteins function in the ZMM pathway, which in Arabidopsis includes MSH4, MSH5, SHOC1, ZIP4, PTD, MER3, ZYP1 and HEI10 [19,26-35]. Between 80\%-90\% of Arabidopsis crossovers are interfering and the remainder of crossovers are generated via a non-interfering pathway, which includes MUS81 [30,33,36,37] (Figure 1). It is likely that these repair pathways are tightly coordinated and the FANCM helicase is known to play a key role in governing the balance between non-crossovers and non-interfering crossovers $[38,39]$. The net effect of these repair pathways is that most homologues have at least one crossover and that multiple crossovers are rare. As a larger number of DSBs are generated than eventually form crossovers, this also means crossover locations are different between meioses.

\section{Plant crossover hotspots at gene promoters and terminators}

The frequency of meiotic recombination is highly variable along and between chromosomes, and in many species crossover hotspots and coldspots have been defined [40] (Figure 2). Eukaryotes possess extensive modification of DNA and histones, for example, cytosine methylation and histone methylation, acetylation, ubiquitination and phosphorylation, and these marks are important for gene expression and chromosome function [41,42]. Many of these modifications, for example, DNA methylation, are also epigenetically inherited through DNA replication [41,42]. Increasing evidence has shown that recombination frequency in plants is strongly influenced by chromatin and epigenetic information [43-48].

Plant genomes show strong correlations between gene density and crossover frequency, which is particularly evident in species with large genomes, where gene densities are skewed. For example, maize $(2.5 \mathrm{~Gb})$, barley $(5.1 \mathrm{~Gb})$, wheat $(17 \mathrm{~Gb})$ and tomato $(950 \mathrm{Mb})$ all show pronounced elevations in crossover frequency and gene density towards the sub-telomeres, with large central regions of high repeat density and suppressed crossovers [6,49-53]. Fine-scale (kb) genetic mapping in maize has also demonstrated that crossovers are associated with genes and repressed in transposons [54-59]. Analysis of historical and experimental crossovers in Arabidopsis has shown that recombination is associated with gene promoter and terminator sites [43-45,60] (Figure 3). Historical recombination analysis in Mimulus also showed crossover enrichment at gene transcriptional start sites (TSSs) and termination sites (TTSs) [61]. The 

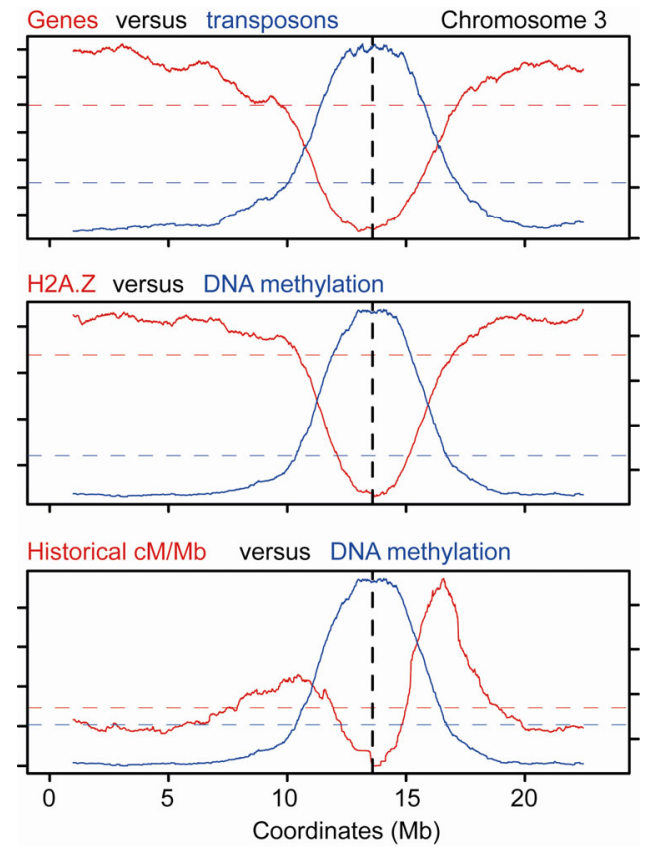

Figure 2 Epigenetic domains and the Arabidopsis recombination landscape. Plots are shown for Arabidopsis thaliana chromosome 3 with gene versus transposon density, H2A.Z [65] versus DNA methylation [91], or historical Eurasian crossover frequency $(\mathrm{cM} / \mathrm{Mb})$ [44] versus DNA methylation. Recombination is observed predominantly in the gene-rich, H2A.Z-dense chromosome arms and excluded from the transposon-rich, DNA methylation dense centromeric regions.

chromatin architecture of gene promoters and terminators is important for accurate and productive RNA pol-II transcription [62]. For example, immediately upstream of TSSs are nucleosome free regions with low DNA methylation, where Pol-II binds and initiates transcription [63]. The first $(+1)$ nucleosome downstream of TSS is highly positioned, con- tains the histone variant H2A.Z and is modified with $\mathrm{H} 3 \mathrm{~K} 4$ trimethylation $(\mathrm{H} 3 \mathrm{~K} 4 \mathrm{me} 3)$ and these features are important for promotion of gene transcription [64-67]. Interestingly, both the Arabidopsis and Mimulus historical recombination signals overlap the +1 H2A.Z-containing nucleosome [44,61] (Figure 3). This overlap has functional significance as crossover frequency is reduced at multiple scales in the Arabidopsis arp6 mutant, which fails to deposit H2A.Z in chromatin [44]. Together this suggests that the meiotic recombination machinery in plants is recruited by geneassociated chromatin marks. We speculate that this reflects a mechanism to concentrate recombination around selectively important sequences in gene-rich regions.

In budding yeast meiotic DSBs occur mostly in nucleosome depleted regions at gene promoters $[9,68]$. High H3K4me3 levels are also associated with DSBs in budding yeast and removal of this epigenetic mark alters formation of DSBs [69-72]. Many DSB hotspots are reduced in set1, but loci also exist that show increased DSBs [69]. The Spp1 subunit of the Set1 (COMPASS) complex has been found to recognize $\mathrm{H} 3 \mathrm{~K} 4 \mathrm{me} 3$ at gene promoters and also to interact with the meiotic chromosome axis protein Mer2 [69-72], consistent with the tethered chromatin loop-axis model [73-75]. As H3K4 methylation is also enriched over plant promoter hotspots, it will be interesting to investigate the extent to which this mechanism is conserved $[44,45,58,60]$. In Arabidopsis over-expression of a histone N-acetyltransferase MEIOTIC CONTROL OF CROSSOVERS I (MCCI) leads to increased $\mathrm{H} 3$ acetylation, aberrant chromosome axes and alters chiasma number and distributions [76]. Specifically, chiasmata were reduced in chromosomes 1 and 2 and increased in chromosome 4, with the latter acquiring more events on the short arm where repeat rDNA NOR ar-
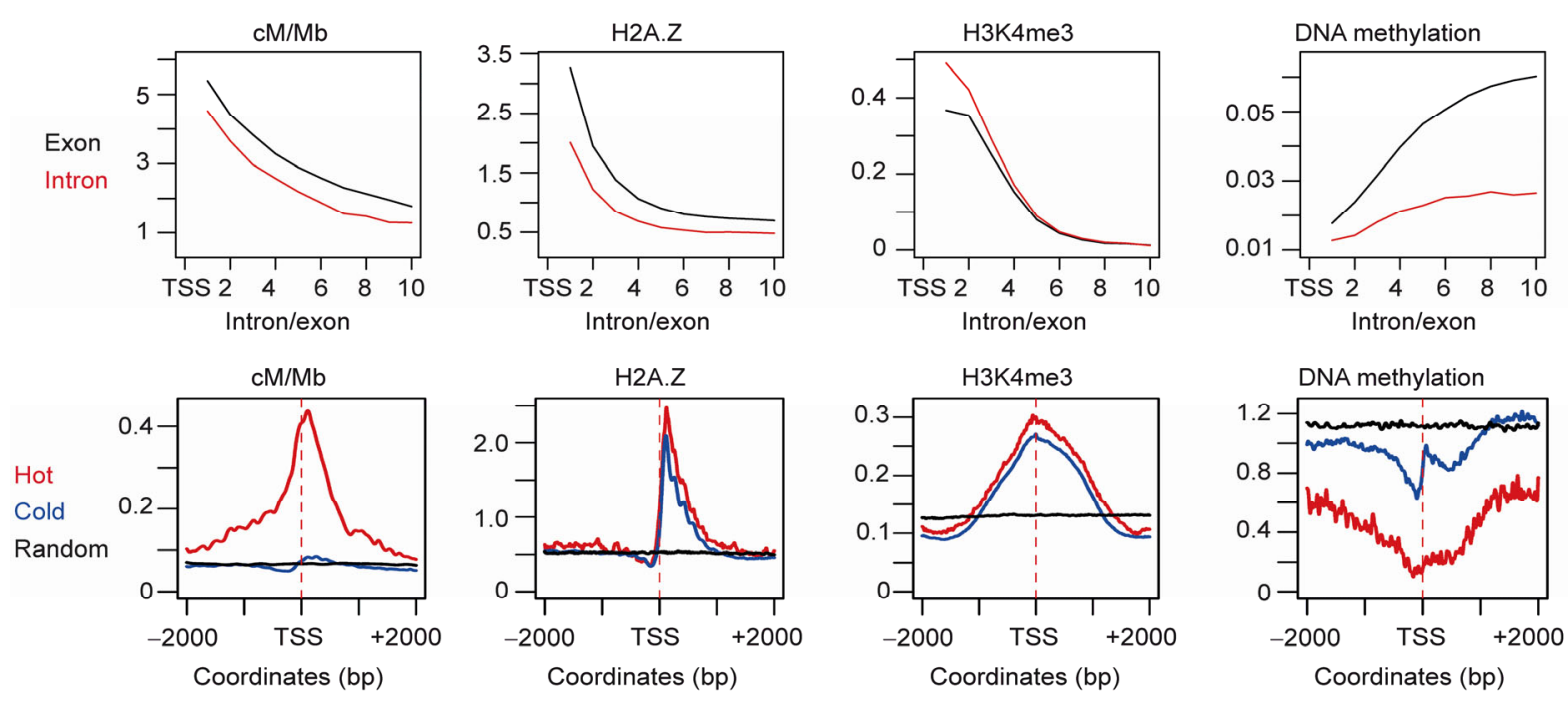

Figure 3 Recombination and chromatin patterns at Arabidopsis gene promoter hotspots. Plots show historical Eurasian crossover frequency (cM/Mb) [44], H2A.Z [65], histone 3 lysine 4 trimethylation (H3K4me3) [67], and DNA methylation [91] in relation to gene features. The upper panels show the listed parameter for intron (red) and exon (blacks) positions at increasing distances from gene transcriptional start sites (TSSs). The lower panels show parameter density in $4 \mathrm{~kb}$ windows around TSS for hotspot promoters (red), coldspot promoters (blue) or randomly chosen positions. 
rays are located [76]. Further work is required to determine how gene-associated chromatin marks interact to influence plant meiotic recombination at hotspot and domain scales.

Analysis of Arabidopsis recombination hotspots has identified a class of CTT-repeat motifs associated with crossovers $[44,45]$. Historical recombination and the CTTrepeat motif are both coincident with the +1 nucleosome [44]. The function of this motif is presently unclear but one possibility is that it contributes to positioning of the $+1 \mathrm{nu}-$ cleosome, which then has consequences on recombination. Alternatively, recombination may contribute to motif formation in a similar way to microsatellites [77]. A-rich motifs were also detected upstream of TSSs, coincident with regions of low nucleosome density [44]. These motifs are most likely to contribute to nucleosome exclusion, which may then facilitate access of recombination proteins, such as Spo11 [9]. Recombination also associates with genetic diversity in many species $[49,78,79]$, which may relate to potential mutagenic consequences of recombination. For example, conversion of $\mathrm{A}: \mathrm{T}$ to $\mathrm{G}: \mathrm{C}$ is thought to occur during meiotic recombination due to an inherent GC-bias in the mismatch repair machinery [80]. Targeting of crossover hotspots to gene promoters may be ancestral within eukaryotes, as it is shared between budding yeast and plants $[9,44,45,61]$. In contrast, mammalian hotspot locations are controlled by the PRDM9 protein, which directs hotspots to specific DNA motifs [81-83]. However, in prdm9 mutant mouse recombination hotspots revert to promoter locations [84]. Therefore, PRDM9 is likely to be a derived hotspot targeting mechanism, consistent with it so far not being identified outside of animals [85].

\section{Crossover suppression by plant hetero- chromatin}

Plant transposons and repeats typically form heterochromatin and are densely modified by DNA cytosine methylation, histone $\mathrm{H} 3 \mathrm{~K} 9$ dimethylation (H3K9me2) and accumulate high levels of complementary small RNAs [41,42]. While these regions exclude Pol-II transcription, they are actively transcribed by two plant specific RNA-polymerases Pol-IV and Pol-V [86]. These polymerases generate RNA molecules that serve as substrates for small RNA generation, which can then guide de novo DNA methyltransferase to homologous sequences-this pathway is termed RNAdirected DNA methylation [41,42]. Pol-IV and Pol-V are themselves recruited by heterochromatic marks which creates a self-reinforcing and stable epigenetic loop [87-89]. Plant genomes show tight chromatin state transitions between adjacent genes and transposons, and maintenance of these boundaries can involve histone demethylation [90-92]. In Arabidopsis there is a marked increase in repeat density and heterochromatin in the regions surrounding the centromeres, though dispersed repeats also occur within the gene- rich arms [90,91,93] (Figure 2). The heterochromatic regions, including the centromeres, are suppressed for both Pol-II transcription and meiotic crossover [21,91,93,94]. It may be beneficial to suppress recombination in repetitive regions due to a high chance of illegitimate, non-allelic recombination, which could potentially be damaging to genome integrity. For example, centromere proximal crossovers are associated with chromosome non-disjunction in humans [95].

The role of heterochromatic marks in crossover suppression has been experimentally tested. For example, targeted de novo DNA methylation in Ascobolus immerses is sufficient to suppress crossovers by over a 100-fold [96]. In plants the role of DNA methylation has been addressed using mutants in the MET1 cytosine methyltransferase or DDM1 chromatin remodeling factor [43,46-48]. MET1 and DDM1 function together to maintain DNA methylation epigenetically across DNA replication forks [90,93,97-99]. As a consequence the metl and $d d m l$ mutations show a dramatic loss of DNA methylation, heterochromatin and ectopic Pol-II transcription of repeats and transposons $[91,98,100,101]$. These changes are most dramatic in the repetitive regions surrounding the centromeres. Recombination rates show epigenetic remodeling in met 1 and $d d m 1$ mutants [43,46-48]. Specifically, crossovers increase in the gene-rich chromosome arms and decrease in the pericentromeric regions [43,46-48]. However, total crossover levels are similar between wild type and met 1 , indicating that remodeling of crossovers had occurred, rather than global increases or decreases [43]. These observations were unexpected as the regions of de-repressed heterochromatin might be predicted to show elevated crossovers. However, while it is possible that early meiotic recombination steps are increased in repetitive regions in metl and $d d m 1$, compensatory changes related to crossover interference/homeostasis, or other feedback mechanisms, could trigger the observed crossover remodeling $[26,102,103]$. Understanding these effects will require more detailed work profiling the different steps of the recombination mechanism in met 1 and $d d m 1$. For example, while Spo11 accessibility may be influenced by changes in DNA methylation, it is also possible that strand invasion or other downstream recombination events could be changed. Small RNAs have also been implicated in control of meiotic progression in rice where the MEIOSIS ARRESTED AT LEPTOTENE (MEL1) ARGONAUTE protein is required for germ cell development and meiotic homologous chromosome synapsis [104,105]. ARGONAUTE proteins bind small RNAs and mediate base-pairing interactions with target nucleic acids. The exact function of MELl during meiosis is unknown, though it has a modest effect on heterochromatin (H3K9me2) in pericentromeric regions and binds germlinespecific 21-nt phased small RNAs (phasiRNAs) [104,105]. Therefore, it is possible that MEL1 directly regulates meiotic chromosomes or that it may control a factor required 
for progression of meiosis.

\section{Chromatin structure, the meiotic chromo- some axes and homologous recombination}

Electron-microscopy has revealed that meiotic chromatin is organized in loop-base arrays along an underlying chromosome axis $[73,106]$. Formation of the meiotic axis initiates after S-phase and prior to DSB formation [107]. In budding yeast mutations in the axis components Rec8, Hop1 and Red1 result in reduced DSB formation [107-111]. Spo11dependent DSBs form on the chromatin loops that are tethered to the axis, and DSBs are subsequently repaired at the axis via interactions between axis proteins and Spo11accessory factors $[70,71,74,75]$. Remodeling of the meiotic axes is tightly coordinated with the progression of DNA repair and crossover formation [112,113]. During mid-prophase I, following DSB formation, recombination interactions between homologues favors chromosome alignment and synaptonemal complex (SC) formation in budding yeasts, plants and mice; but not in C. elegans and female Drosophila where SC formation is independent of DSBs [14,114-117]. The SC has a tripartite proteinaceous structure comprising two homologous axes, referred to as lateral elements, which are linked to a central element by transverse filaments [118]. Interestingly, partial depletion of the synaptonemal complex component SYP-1 in C. elegans reduces crossover interference and thereby increases crossover frequency, indicating this structure can restrict crossover recombination [119].

The composition of plant meiotic axes has been studied through genetic screens, immunocytochemistry and biochemistry [120]. Two major Arabidopsis axis components are ASY1 and ASY3, which share structural and functional similarities with budding yeast Hop1 and Red1, respectively [20,121-123]. In the absence of ASY1, the duration of DMC1 association with chromatin is shortened and inter-homolog crossover formation is significantly reduced [121]. A less severe defect in crossover formation is observed in asy3 mutants, and asyl is epistatic to asy3 for inter-homolog crossover formation [20]. ASY1 forms chromatin foci in asy3 but its signal fails to linearize, indicating that ASY1 polymerisation is dependent on ASY3 [20]. Importantly, ASY1 foci are SPO11 independent, suggesting that axis formation is not dependent on meiotic DSBs and may be recruited by pre-existing chromosomal features [20]. ASY1 foci have also been observed to alternate with H2A.Z foci on meiotic chromosomes, which may reflect loop-axis chromosome structure and formation of DSBs on loops away from the axis [44].

The axis also includes the cohesin complex, which forms a ring-structure comprising Structural Maintenance of Chromosome (SMC) family members SMC1 and SMC3, $\alpha$-kleisin SYN1/SCC1/REC8/DIF1 and SCC3 [124-128].
Cohesin formation is established between sister chromatids during meiotic S-phase and is maintained along the chromosome arms during prophase I [124,127,128]. Arabidopsis rec8 mutants display chromosome fragmentation and chromatin bridges, which can be recovered in a rec 8 spoll double mutant, indicating a role for the cohesin complex in promoting recombination and DNA repair [124-127]. Chromatin immunoprecipitation of cohesin components in budding yeast has shown that it co-localises with other axis proteins and is required for normal axis associations with chromatin [74,75,129]. A further important function of cohesin complexes is to prevent sister chromatids separating during the first meiotic division [130]. At anaphase-I cohesin is lost from the chromosome arms via protein degradation, allowing homologous chromosomes to separate [131,132]. Cohesin remains at centromeric regions until anaphase-II, when its degradation allows the separation of sister chromatids into separate gametes [131,132]. REC8 is protected in the centromeric regions during anaphase-I by the SHUGOSHIN protein and later by PATRONUS [133-136]. It will be interesting to integrate our understanding of chromatin with that of the meiotic axis, as these factors are likely to interact to influence recombination control.

\section{Prospects}

In recent years it has become clear that patterns of Pol-II transcription on eukaryotic chromosomes cannot be understood without a complete understanding of their epigenetic organization. Emerging data from plants and other systems indicate that this is also the case for meiotic recombination. However, out of a vast array of epigenetic modifications of DNA and chromatin only a handful have been studied in relation to their effect on meiotic recombination and chromosome behavior. Profiling DSBs and crossovers genome-wide, as well as cytogenetic studies of meiotic progression in plants with altered epigenetic landscapes, will be of interest. It will be important to determine how chromatin marks are involved in tethering and positioning components of meiotic recombination machinery to specific genomic locations. Understanding meiotic recombination will be important as it has a significant influence on genetic diversity and speciation, for example, axis proteins have been implicated in the evolution of polyploid Arabidopsis species $[137,138]$. In addition, knowledge of how crossovers are controlled will allow this process to be manipulated in useful ways in crop species [6].

1 Villeneuve AM, Hillers KJ. Whence meiosis? Cell, 2001, 106: 647-650

2 Wilkins AS, Holliday R. The evolution of meiosis from mitosis. Genetics, 2009, 181: 3-12

3 Cavalier-Smith T. Origins of the machinery of recombination and sex. 
Heredity (Edinb), 2002, 88: 125-141

4 Barton NH, Charlesworth B. Why sex and recombination? Science, 1998, 281: 1986-1990

5 Hamilton WD. Narrow Roads of Gene Land: the Collected Papers of W.D Hamilton. Volume 2 The Evolution of Sex. Oxford: Oxford University Press, 2001

6 Higgins JD, Osman K, Jones GH, Franklin FCH. Factors underlying restricted crossover localization in barley meiosis. Annu Rev Genet, 2014, 48: 29-47

7 Keeney S, Giroux CN, Kleckner N. Meiosis-specific DNA double-strand breaks are catalyzed by Spo11, a member of a widely conserved protein family. Cell, 1997, 88: 375-384

8 Bergerat A, de Massy B, Gadelle D, Varoutas PC, Nicolas A, Forterre P. An atypical topoisomerase II from Archaea with implications for meiotic recombination. Nature, 1997, 386: 414-417

9 Pan J, Sasaki M, Kniewel R, Murakami H, Blitzblau HG, Tischfield SE, Zhu X, Neale MJ, Jasin M, Socci ND, Hochwagen A, Keeney S. A hierarchical combination of factors shapes the genome-wide topography of yeast meiotic recombination initiation. Cell, 2011, 144: 719-731

10 Neale MJ, Pan J, Keeney S. Endonucleolytic processing of covalent protein-linked DNA double-strand breaks. Nature, 2005, 436: 1053-1057

11 Garcia V, Phelps SE, Gray S, Neale MJ. Bidirectional resection of DNA double-strand breaks by Mre11 and Exo1. Nature, 2011, 479: 241-244

12 Bishop DK, Park D, Xu L, Kleckner N. DMC1: a meiosis-specific yeast homolog of $E$. coli recA required for recombination, synaptonemal complex formation, and cell cycle progression. Cell, 1992, 69: 439-456

13 Shinohara A, Ogawa H, Ogawa T. Rad51 protein involved in repair and recombination in S. cerevisiae is a RecA-like protein. Cell, 1992, 69: $457-470$

14 Grelon M, Vezon D, Gendrot G, Pelletier G. AtSPO11-1 is necessary for efficient meiotic recombination in plants. EMBO J, 2001, 20: 589-600

15 Couteau F, Belzile F, Horlow C, Grandjean O, Vezon D, Doutriaux MP. Random chromosome segregation without meiotic arrest in both male and female meiocytes of a dmc1 mutant of Arabidopsis. Plant Cell, 1999, 11: 1623-1634

16 Youds JL, Boulton SJ. The choice in meiosis-defining the factors that influence crossover or non-crossover formation. J Cell Sci, 2011, 124: 501-513

17 McMahill MS, Sham CW, Bishop DK. Synthesis-dependent strand annealing in meiosis. PLoS Biol, 2007, 5: e299

18 Keeney S, Neale MJ. Initiation of meiotic recombination by formation of DNA double-strand breaks: mechanism and regulation. Biochem Soc Trans, 2006, 34: 523-525

19 Chelysheva L, Vezon D, Chambon A, Gendrot G, Pereira L, Lemhemdi A, Vrielynck N, Le Guin S, Novatchkova M, Grelon M. The Arabidopsis HEI10 is a new ZMM protein related to Zip3. PLoS Genet, 2012, 8: e1002799

20 Ferdous M, Higgins JD, Osman K, Lambing C, Roitinger E, Mechtler K, Armstrong SJ, Perry P, Pradillo M, Cunado N, Franklin FC. Inter-homolog crossing-over and synapsis in Arabidopsis meiosis are dependent on the chromosome axis protein AtASY3. PLoS Genet, 2012, 8: e1002507

21 Giraut L, Falque M, Drouaud J, Pereira L, Martin OC, Mézard C. Genome-wide crossover distribution in Arabidopsis thaliana meiosis reveals sex-specific patterns along chromosomes. PLoS Genet, 2011, 7: e1002354

22 Salomé PA, Bomblies K, Fitz J, Laitinen RA, Warthmann N, Yant L, Weigel D. The recombination landscape in Arabidopsis thaliana F2 populations. Heredity, 2012, 108: 447-455

23 Lynn A, Soucek R, Börner GV. ZMM proteins during meiosis: crossover artists at work. Chromosome Res, 2007, 15: 591-605

24 Muller HJ. The mechanism of crossing-over. Am Nat, 1916, 50: $193-221$
25 Sturtevant AH. The behavior of the chromosomes as studied through linkage. Zeitschrift fur Indukt. Abstammungs und Vererbungslehre, 1915, 13: 234-287

26 Copenhaver GP, Housworth EA, Stahl FW. Crossover interference in Arabidopsis. Genetics, 2002, 160: 1631-1639

27 Chelysheva L, Grandont L, Vrielynck N, Le Guin S, Mercier R, Grelon M. An easy protocol for studying chromatin and recombination protein dynamics during Arabidopsis thaliana meiosis: immunodetection of cohesins, histones and MLH1. Cytogenet Genome Res, 2010, 129: 143-153

28 Chelysheva L, Gendrot G, Vezon D, Doutriaux MP, Mercier R, Grelon M. Zip4/Spo22 is required for class I CO formation but not for synapsis completion in Arabidopsis thaliana. PLoS Genet, 2007, 3: e83

29 Chen C, Zhang W, Timofejeva L, Gerardin Y, Ma H. The Arabidopsis ROCK-N-ROLLERS gene encodes a homolog of the yeast ATP-dependent DNA helicase MER3 and is required for normal meiotic crossover formation. Plant J, 2005, 43: 321-334

30 Higgins JD, Armstrong SJ, Franklin FCH, Jones GH. The Arabidopsis MutS homolog AtMSH4 functions at an early step in recombination: evidence for two classes of recombination in Arabidopsis. Genes Dev, 2004, 18: 2557-2570

31 Higgins JD, Vignard J, Mercier R, Pugh AG, Franklin FC, Jones GH. AtMSH5 partners AtMSH4 in the class I meiotic crossover pathway in Arabidopsis thaliana, but is not required for synapsis. Plant J, 2008, 55: $28-39$

32 Macaisne N, Novatchkova M, Peirera L, Vezon D, Jolivet S, Froger $\mathrm{N}$, Chelysheva L, Grelon M, Mercier R. SHOC1, an XPF endonuclease-related protein, is essential for the formation of class I meiotic crossovers. Curr Biol, 2008, 18: 1432-1437

33 Mercier R, Jolivet S, Vezon D, Huppe E, Chelysheva L, Giovanni M, Noqué F, Doutriaux MP, Horlow C, Grelon M, Mézard C. Two meiotic crossover classes cohabit in Arabidopsis: one is dependent on MER3, whereas the other one is not. Curr Biol, 2005, 15: 692-701

34 Wijeratne AJ, Chen C, Zhang W, Timofejeva L, Ma H. The Arabidopsis thaliana PARTING DANCERS gene encoding a novel protein is required for normal meiotic homologous recombination. Mol Biol Cell, 2006, 17: 1331-1343

35 Higgins JD, Sanchez-Moran E, Armstrong SJ, Jones GH, Franklin FCH. The Arabidopsis synaptonemal complex protein ZYP1 is required for chromosome synapsis and normal fidelity of crossing over. Genes Dev, 2005, 19: 2488-2500

36 Higgins JD, Buckling EF, Franklin FCH, Jones GH. Expression and functional analysis of AtMUS81 in Arabidopsis meiosis reveals a role in the second pathway of crossing-over. Plant J, 2008, 54: 152-162

37 Berchowitz LE, Francis KE, Bey AL, Copenhaver GP. The role of AtMUS81 in interference-insensitive crossovers in A. thaliana. PLoS Genet, 2007, 3: e132

38 Crismani W, Girard C, Froger N, Pradillo M, Santos JL, Chelysheva L, Copenhaver GP, Horlow C, Mercier R. FANCM limits meiotic crossovers. Science, 2012, 336: 1588-1590

39 Knoll A, Higgins JD, Seeliger K, Reha SJ, Dangel NJ, Bauknecht M, Schröpfer S, Franklin FC, Puchta H. The Fanconi anemia ortholog FANCM ensures ordered homologous recombination in both somatic and meiotic cells in Arabidopsis. Plant Cell, 2012, 24: 1448-1464

40 Kauppi L, Jeffreys AJ, Keeney S. Where the crossovers are: recombination distributions in mammals. Nat Rev Genet, 2004, 5: 413-424

41 Law JA, Jacobsen SE. Establishing, maintaining and modifying DNA methylation patterns in plants and animals. Nat Rev Genet, 2010, 11: 204-220

42 Henderson IR, Jacobsen SE. Epigenetic inheritance in plants. Nature, 2007, 447: 418-424

43 Yelina NE, Choi K, Chelysheva L, Macaulay M, de Snoo B, Wijnker E, Miller N, Drouaud J, Grelon M, Copenhaver GP, Mezard C, Kelly KA, Henderson IR. Epigenetic remodeling of meiotic crossover frequency in Arabidopsis thaliana DNA methyltransferase mutants. PLoS Genet, 2012, 8: e1002844 
44 Choi K, Zhao X, Kelly KA, Venn O, Higgins JD, Yelina NE, Hardcastle TJ, Ziolkowski PA, Copenhaver GP, Franklin FC, McVean G, Henderson IR. Arabidopsis meiotic crossover hot spots overlap with H2A.Z nucleosomes at gene promoters. Nat Genet, 2013, 45: 1327-1336

45 Wijnker E, Velikkakam JG, Ding J, Becker F, Klasen JR, Rawat V, Rowan BA, de Jong DF, de Snoo CB, Zapata L, Huettel B, de Jong H, Ossowski S, Weigel D, Koornneef M, Keurentjes JJ, Schneeberger K. The genomic landscape of meiotic crossovers and gene conversions in Arabidopsis thaliana. eLIFE, 2013, 2: e01426

46 Melamed-Bessudo C, Levy AA. Deficiency in DNA methylation increases meiotic crossover rates in euchromatic but not in heterochromatic regions in Arabidopsis. Proc Natl Acad Sci USA, 2012, 109: E981-988

47 Colomé-Tatché M, Cortijo S, Wardenaar R, Morgado L, Lahouze B, Sarazin A, Etcheverry M, Martin A, Feng S, Duvernois-Berthet E, Labadie K, Wincker P, Jacobsen SE, Jansen RC, Colot V, Johannes F. Features of the Arabidopsis recombination landscape resulting from the combined loss of sequence variation and DNA methylation. Proc Natl Acad Sci USA, 2012, 109: 16240-16245

48 Mirouze M, Lieberman-Lazarovich M, Aversano R, Bucher E, Nicolet J, Reinders J, Paszkowski J. Loss of DNA methylation affects the recombination landscape in Arabidopsis. Proc Natl Acad Sci USA, 2012, 109: 5880-5885

49 Gore MA, Chia JM, Elshire RJ, Sun Q, Ersoz ES, Hurwitz BL, Peiffer JA, McMullen MD, Grills GS, Ross-Ibarra J, Ware DH, Buckler ES. A first-generation haplotype map of maize. Science, 2009, 326: 1115-1117

50 International Barley Genome Sequencing Consortium. A physical, genetic and functional sequence assembly of the barley genome. Nature, 2012, 491: 711-716

51 Tomato Genome Consortium. The tomato genome sequence provides insights into fleshy fruit evolution. Nature, 2012, 485: 635-641

52 Wei F, Zhang J, Zhou S, He R, Schaeffer M, Collura K, Kudrna D, Faga BP, Wissotski M, Golser W, Rock SM, Graves TA, Fulton RS, Coe E, Schnable PS, Schwartz DC, Ware D, Clifton SW, Wilson RK, Wing RA. The physical and genetic framework of the maize B73 genome. PLoS Genet, 2009, 5: e1000715

53 International Wheat Genome Sequencing Consortium (IWGSC). A chromosome-based draft sequence of the hexaploid bread wheat (Triticum aestivum) genome. Science, 2014, 345: 1251788-11251788-11

54 Dooner HK, Martínez-Férez IM. Recombination occurs uniformly within the bronze gene, a meiotic recombination hotspot in the maize genome. Plant Cell, 1997, 9: 1633-1646

55 Dooner $\mathrm{HK}, \mathrm{He} \mathrm{L}$. Maize genome structure variation: interplay between retrotransposon polymorphisms and genic recombination. Plant Cell, 2008, 20: 249-258

$56 \mathrm{Fu} \mathrm{H}$, Zheng Z, Dooner HK. Recombination rates between adjacent genic and retrotransposon regions in maize vary by 2 orders of magnitude. Proc Natl Acad Sci USA, 2002, 99: 1082-1087

57 Fu H, Park W, Yan X, Zheng Z, Shen B, Dooner HK. The highly recombinogenic bz locus lies in an unusually gene-rich region of the maize genome. Proc Natl Acad Sci USA, 2001, 98: 8903-8908

58 Liu S, Yeh CT, Ji T, Ying K, Wu H, Tang HM, Fu Y, Nettleton D, Schnable PS. Mu transposon insertion sites and meiotic recombination events co-localize with epigenetic marks for open chromatin across the maize genome. PLoS Genet, 2009, 5: e1000733

59 Yao H, Zhou Q, Li J, Smith H, Yandeau M, Nikolau BJ, Schnable PS. Molecular characterization of meiotic recombination across the 140-kb multigenic a1-sh2 interval of maize. Proc Natl Acad Sci USA, 2002, 99: 6157-6162

60 Drouaud J, Khademian H, Giraut L, Zanni V, Bellalou S, Henderson IR, Falque M, Mézard C. Contrasted patterns of crossover and non-crossover at Arabidopsis thaliana meiotic recombination hotspots. PLoS Genet, 2013, 9: e1003922

61 Hellsten U, Wright KM, Jenkins J, Shu S, Yuan Y, Wessler SR, Schmutz J, Willis JH, Rokhsar DS. Fine-scale variation in meiotic recombination in Mimulus inferred from population shotgun sequencing. Proc Natl Acad Sci USA, 2013, 110: 19478-19482

62 Venters BJ, Pugh BF. How eukaryotic genes are transcribed. Crit Rev Biochem Mol Biol, 2009, 44: 117-141

63 Chodavarapu RK, Feng S, Bernatavichute YV, Chen PY, Stroud H, Yu Y, Hetzel JA, Kuo F, Kim J, Cokus SJ, Casero D, Bernal M, Huijser P, Clark AT, Krämer U, Merchant SS, Zhang X, Jacobsen SE, Pellegrini M. Relationship between nucleosome positioning and DNA methylation. Nature, 2010, 466: 388-392

64 Zilberman D, Coleman-Derr D, Ballinger T, Henikoff S. Histone H2A.Z and DNA methylation are mutually antagonistic chromatin marks. Nature, 2008, 456: 125-129

65 Coleman-Derr D, Zilberman D. Deposition of histone variant H2A.Z within gene bodies regulates responsive genes. PLoS Genet, 2012, 8: e1002988

66 Kumar SV, Wigge PA. H2A.Z-containing nucleosomes mediate the thermosensory response in Arabidopsis. Cell, 2010, 140: 136-147

67 Zhang X, Bernatavichute YV, Cokus S, Pellegrini M, Jacobsen SE. Genome-wide analysis of mono-, di- and trimethylation of histone H3 lysine 4 in Arabidopsis thaliana. Genome Biol, 2009, 10: R62

$68 \mathrm{Wu}$ TC, Lichten M. Meiosis-induced double-strand break sites determined by yeast chromatin structure. Science, 1994, 263: 515-518

69 Borde V, Robine N, Lin W, Bonfils S, Géli V, Nicolas A. Histone H3 lysine 4 trimethylation marks meiotic recombination initiation sites. EMBO J, 2009, 28: 99-111

70 Acquaviva L, Székvölgyi L, Dichtl B, Dichtl BS, de La Roche Saint-André C, Nicolas A, Géli V. The COMPASS subunit Spp1 links histone methylation to initiation of meiotic recombination. Science, 2013, 339: 215-218

71 Sommermeyer V, Béneut C, Chaplais E, Serrentino ME, Borde V. Spp1, a member of the Set1 Complex, promotes meiotic DSB formation in promoters by tethering histone $\mathrm{H} 3 \mathrm{~K} 4$ methylation sites to chromosome axes. Mol Cell, 2013, 49: 43-54

72 Sollier J, Lin W, Soustelle C, Suhre K, Nicolas A, Géli V, de La Roche Saint-André C. Set1 is required for meiotic S-phase onset, double-strand break formation and middle gene expression. EMBO J, 2004, 23: 1957-1967

73 Kleckner N. Chiasma formation: chromatin/axis interplay and the role(s) of the synaptonemal complex. Chromosoma, 2006, 115: 175-194

74 Panizza S, Mendoza MA, Berlinger M, Huang L, Nicolas A, Shirahige K, Klein F. Spo11-accessory proteins link double-strand break sites to the chromosome axis in early meiotic recombination. Cell, 2011, 146: 372-383

75 Blat Y, Protacio RU, Hunter N, Kleckner N. Physical and functional interactions among basic chromosome organizational features govern early steps of meiotic chiasma formation. Cell, 2002, 111: 791-802

76 Perrella G, Consiglio MF, Aiese-Cigliano R, Cremona G, Sanchez-Moran E, Barra L, Errico A, Bressan RA, Franklin FC, Conicella C. Histone hyperacetylation affects meiotic recombination and chromosome segregation in Arabidopsis. Plant J, 2010, 62: 796-806

77 Jeffreys AJ, Allen MJ, Armour JAL, Collick A, Dubrova Y, Fretwell N, Guram T, Jobling M, May CA, Neil DL, Neumann R. Mutation processes at human minisatellites. Electrophoresis, 1995, 16: 1577-1585

78 Paape T, Zhou P, Branca A, Briskine R, Young N, Tiffin P. Fine-scale population recombination rates, hotspots, and correlates of recombination in the Medicago truncatula genome. Genome Biol Evol, 2012, 4: 726-737

79 Cao J, Schneeberger K, Ossowski S, Günther T, Bender S, Fitz J, Koenig D, Lanz C, Stegle O, Lippert C, Wang X, Ott F, Müller J, Alonso-Blanco C, Borgwardt K, Schmid KJ, Weigel D. Whole-genome sequencing of multiple Arabidopsis thaliana populations. Nat Genet, 2011, 43: 956-963

80 Duret L, Galtier N. Biased gene conversion and the evolution of mammalian genomic landscapes. Annu Rev Genomics Hum Genet, 2009, 10: 285-311

81 Baudat F, Buard J, Grey C, Fledel-Alon A, Ober C, Przeworski M, 
Coop G, de Massy B. PRDM9 is a major determinant of meiotic recombination hotspots in humans and mice. Science, 2010, 327: 836-840

82 Myers S, Bowden R, Tumian A, Bontrop RE, Freeman C, MacFie TS, McVean G, Donnelly P. Drive against hotspot motifs in primates implicates the PRDM9 gene in meiotic recombination. Science, 2010, 327: 876-879

83 Parvanov ED, Petkov PM, Paigen K. Prdm9 controls activation of mammalian recombination hotspots. Science, 2010, 327: 835

84 Brick K, Smagulova F, Khil P, Camerini-Otero RD, Petukhova GV. Genetic recombination is directed away from functional genomic elements in mice. Nature, 2012, 485: 642-645

85 Oliver PL, Goodstadt L, Bayes JJ, Birtle Z, Roach KC, Phadnis N, Beatson SA, Lunter G, Malik HS, Ponting CP. Accelerated evolution of the Prdm9 speciation gene across diverse metazoan taxa. PLoS Genet, 2009, 5: e1000753

86 Haag JR, Pikaard CS. Multisubunit RNA polymerases IV and V: purveyors of non-coding RNA for plant gene silencing. Nat Rev Mol Cell Biol, 2011, 12: 483-492

87 Zhong X, Hale CJ, Law JA, Johnson LM, Feng S, Tu A, Jacobsen SE. DDR complex facilitates global association of RNA polymerase $\mathrm{V}$ to promoters and evolutionarily young transposons. Nat Struct Mol Biol, 2012, 19: 870-875

88 Law JA, Du J, Hale CJ, Feng S, Krajewski K, Palanca AM, Strahl BD, Patel DJ, Jacobsen SE. Polymerase IV occupancy at RNA-directed DNA methylation sites requires SHH1. Nature, 2013, 498: 385-389

89 Johnson LM, Du J, Hale CJ, Bischof S, Feng S, Chodavarapu RK, Zhong X, Marson G, Pellegrini M, Segal DJ, Patel DJ, Jacobsen SE. SRA- and SET-domain-containing proteins link RNA polymerase V occupancy to DNA methylation. Nature, 2014, 507: 124-128

90 Lippman Z, Gendrel AV, Black M, Vaughn MW, Dedhia N, McCombie WR, Lavine K, Mittal V, May B, Kasschau KD, Carrington JC, Doerge RW, Colot V, Martienssen R. Role of transposable elements in heterochromatin and epigenetic control. Nature, 2004, 430: 471-476

91 Cokus SJ, Feng S, Zhang X, Chen Z, Merriman B, Haudenschild CD, Pradhan S, Nelson SF, Pellegrini M, Jacobsen SE. Shotgun bisulphite sequencing of the Arabidopsis genome reveals DNA methylation patterning. Nature, 2008, 452: 215-219

92 Saze H, Shiraishi A, Miura A, Kakutani T. Control of genic DNA methylation by a jmjC domain-containing protein in Arabidopsis thaliana. Science, 2008, 319: 462-465

93 Zhang X, Yazaki J, Sundaresan A, Cokus S, Chan SW, Chen H, Henderson IR, Shinn P, Pellegrini M, Jacobsen SE, Ecker JR. Genome-wide high-resolution mapping and functional analysis of DNA methylation in Arabidopsis. Cell, 2006, 126: 1189-1201

94 Copenhaver GP, Nickel K, Kuromori T, Benito MI, Kaul S, Lin X, Bevan M, Murphy G, Harris B, Parnell LD, McCombie WR, Martienssen RA, Marra M, Preuss D. Genetic definition and sequence analysis of Arabidopsis centromeres. Science, 1999, 286: 2468-2474

95 Lamb NE, Sherman SL, Hassold TJ. Effect of meiotic recombination on the production of aneuploid gametes in humans. Cytogenet Genome Res, 2005, 111: 250-255

96 Maloisel L, Rossignol JL. Suppression of crossing-over by DNA methylation in Ascobolus. Genes Dev, 1998, 12: 1381-1389

97 Kankel MW, Ramsey DE, Stokes TL, Flowers SK, Haag JR, Jeddeloh JA, Riddle NC, Verbsky ML, Richards EJ. Arabidopsis MET1 cytosine methyltransferase mutants. Genetics, 2003, 163: 1109-1122

98 Mathieu O, Reinders J, Caikovski M, Smathajitt C, Paszkowski J. Transgenerational stability of the Arabidopsis epigenome is coordinated by CG methylation. Cell, 2007, 130: 851-862

99 Singer T, Yordan C, Martienssen RA. Robertson's Mutator transposons in A. thaliana are regulated by the chromatin-remodeling gene decrease in DNA Methylation (DDM1). Genes Dev, 2001, 15: 591-602

100 Tariq M, Saze H, Probst AV, Lichota J, Habu Y, Paszkowski J.
Erasure of $\mathrm{CpG}$ methylation in Arabidopsis alters patterns of histone H3 methylation in heterochromatin. Proc Natl Acad Sci USA, 2003, 100: $8823-8827$

101 Vongs A, Kakutani T, Martienssen RA, Richards EJ. Arabidopsis thaliana DNA methylation mutants. Science, 1993, 260: 1926-1928

102 Martini E, Diaz RL, Hunter N, Keeney S. Crossover homeostasis in yeast meiosis. Cell, 2006, 126: 285-295

103 Thacker D, Mohibullah N, Zhu X, Keeney S. Homologue engagement controls meiotic DNA break number and distribution. Nature, 2014, 510: 241-246

104 Komiya R, Ohyanagi H, Niihama M, Watanabe T, Nakano M, Kurata N, Nonomura K. Rice germline-specific Argonaute MEL1 protein binds to phasiRNAs generated from more than 700 lincRNAs. Plant J, 2014, 78: 385-397

105 Nonomura K, Morohoshi A, Nakano M, Eiguchi M, Miyao A, Hirochika H, Kurata N. A germ cell specific gene of the ARGONAUTE family is essential for the progression of premeiotic mitosis and meiosis during sporogenesis in rice. Plant Cell, 2007, 19: 2583-2594

106 Kleckner N, Zickler D, Jones GH, Dekker J, Padmore R, Henle J, Hutchinson J. A mechanical basis for chromosome function. Proc Natl Acad Sci USA, 2004, 101: 12592-12597

107 Kim KP, Weiner BM, Zhang L, Jordan A, Dekker J, Kleckner N. Sister cohesion and structural axis components mediate homolog bias of meiotic recombination. Cell, 2010, 143: 924-937

108 Schwacha A, Kleckner N. Interhomolog bias during meiotic recombination: meiotic functions promote a highly differentiated interhomolog-only pathway. Cell, 1997, 90: 1123-1135

$109 \mathrm{Xu} \mathrm{L}$, Weiner BM, Kleckner N. Meiotic cells monitor the status of the interhomolog recombination complex. Genes Dev, 1997, 11: 106-118

110 Kugou K, Fukuda T, Yamada S, Ito M, Sasanuma H, Mori S, Katou Y, Itoh T, Matsumoto K, Shibata T, Shirahige K, Ohta K. Rec8 guides canonical Spo11 distribution along yeast meiotic chromosomes. Mol Biol Cell, 2009, 20: 3064-3076

111 Mao-Draayer Y, Galbraith AM, Pittman DL, Cool M, Malone RE. Analysis of meiotic recombination pathways in the yeast Saccharomyces cerevisiae. Genetics, 1996, 144: 71-86

112 Börner GV, Barot A, Kleckner N. Yeast Pch2 promotes domainal axis organization, timely recombination progression, and arrest of defective recombinosomes during meiosis. Proc Natl Acad Sci USA, 2008, 105: 3327-3332

113 Deshong AJ, Ye AL, Lamelza P, Bhalla N. A quality control mechanism coordinates meiotic prophase events to promote crossover assurance. PLoS Genet, 2014, 10: e1004291

114 Dernburg AF, McDonald K, Moulder G, Barstead R, Dresser M, Villeneuve AM. Meiotic recombination in C. elegans initiates by a conserved mechanism and is dispensable for homologous chromosome synapsis. Cell, 1998, 94: 387-398

115 Giroux CN, Dresser ME, Tiano HF. Genetic control of chromosome synapsis in yeast meiosis. Genome, 1989, 31: 88-94

116 McKim KS, Green-Marroquin BL, Sekelsky JJ, Chin G, Steinberg C, Khodosh R, Hawley RS. Meiotic synapsis in the absence of recombination. Science, 1998, 279: 876-878

117 Romanienko PJ, Camerini-Otero RD. The mouse Spo11 gene is required for meiotic chromosome synapsis. Mol Cell, 2000, 6: 975-987

118 Page SL, Hawley RS. Chromosome choreography: the meiotic ballet. Science, 2003, 301: 785-789

119 Libuda DE, Uzawa S, Meyer BJ, Villeneuve AM. Meiotic chromosome structures constrain and respond to designation of crossover sites. Nature, 2013, 502: 703-706

120 Osman K, Higgins JD, Sanchez-Moran E, Armstrong SJ, Franklin FCH. Pathways to meiotic recombination in Arabidopsis thaliana. New Phytol, 2011, 190: 523-544

121 Sanchez-Moran E, Santos JL, Jones GH, Franklin FCH. ASY1 mediates AtDMC1-dependent interhomolog recombination during meiosis in Arabidopsis. Genes Dev, 2007, 21: 2220-2233

122 Caryl AP, Armstrong SJ, Jones GH, Franklin FC. A homologue of 
the yeast HOP1 gene is inactivated in the Arabidopsis meiotic mutant asy1. Chromosoma, 2000, 109: 62-71

123 Armstrong SJ, Caryl AP, Jones GH, Franklin FCH. Asy1, a protein required for meiotic chromosome synapsis, localizes to axis-associated chromatin in Arabidopsis and Brassica. J Cell Sci, 2002, 115: 3645-3655

124 Cai X, Dong F, Edelmann RE, Makaroff CA. The Arabidopsis SYN1 cohesin protein is required for sister chromatid arm cohesion and homologous chromosome pairing. J Cell Sci, 2003, 116: 2999-3007

125 Bhatt AM, Lister C, Page T, Fransz P, Findlay K, Jones GH, Dickinson HG, Dean C. The DIF1 gene of Arabidopsis is required for meiotic chromosome segregation and belongs to the REC8/RAD21 cohesin gene family. Plant J, 1999, 19: 463-472

126 Bai X, Peirson BN, Dong F, Xue C, Makaroff CA. Isolation and characterization of SYN1, a RAD21-like gene essential for meiosis in Arabidopsis. Plant Cell, 1999, 11: 417-430

127 Chelysheva L, Diallo S, Vezon D, Gendrot G, Vrielynck N, Belcram K, Rocques N, Márquez-Lema A, Bhatt AM, Horlow C, Mercier R, Mézard C, Grelon M. AtREC8 and AtSCC3 are essential to the monopolar orientation of the kinetochores during meiosis. J Cell Sci, 2005, 118: 4621-4632

128 Lam WS, Yang X, Makaroff CA. Characterization of Arabidopsis thaliana SMC1 and SMC3: evidence that AtSMC3 may function beyond chromosome cohesion. J Cell Sci, 2005, 118: 3037-3048

129 Glynn EF, Megee PC, Yu HG, Mistrot C, Unal E, Koshland DE, DeRisi JL, Gerton JL. Genome-wide mapping of the cohesin complex in the yeast Saccharomyces cerevisiae. PLoS Biol, 2004, 2: E259

130 Watanabe Y. Shugoshin: guardian spirit at the centromere. Curr Opin Cell Biol, 2005, 17: 590-595

131 Buonomo SB, Clyne RK, Fuchs J, Loidl J, Uhlmann F, Nasmyth K. Disjunction of homologous chromosomes in meiosis I depends on proteolytic cleavage of the meiotic cohesin Rec8 by separin. Cell, 2000, 103: 387-398

132 Kitajima TS, Miyazaki Y, Yamamoto M, Watanabe Y. Rec8 cleavage by separase is required for meiotic nuclear divisions in fission yeast. EMBO J, 2003, 22: 5643-5653

133 Zamariola L, De Storme N, Vannerum K, Vandepoele K, Armstrong
SJ, Franklin FC, Geelen D. SHUGOSHINs and PATRONUS protect meiotic centromere cohesion in Arabidopsis thaliana. Plant J, 2014, 77: 782-794

134 Cromer L, Jolivet S, Horlow C, Chelysheva L, Heyman J, De Jaeger G, Koncz C, De Veylder L, Mercier R. Centromeric cohesion is protected twice at meiosis, by SHUGOSHINs at anaphase I and by PATRONUS at interkinesis. Curr Biol, 2013, 23: 2090-2099

135 Kitajima TS, Kawashima SA, Watanabe Y. The conserved kinetochore protein shugoshin protects centromeric cohesion during meiosis. Nature, 2004, 427: 510-517

136 Hamant O, Golubovskaya I, Meeley R, Fiume E, Timofejeva L, Schleiffer A, Nasmyth K, Cande WZ. A REC8-dependent plant Shugoshin is required for maintenance of centromeric cohesion during meiosis and has no mitotic functions. Curr Biol, 2005, 15: 948-954

137 Hollister JD, Arnold BJ, Svedin E, Xue KS, Dilkes BP, Bomblies K. Genetic adaptation associated with genome-doubling in autotetraploid Arabidopsis arenosa. PLoS Genet, 2012, 8: e1003093

138 Yant L, Hollister JD, Wright KM, Arnold BJ, Higgins JD, Franklin FC, Bomblies K. Meiotic adaptation to genome duplication in Arabidopsis arenosa. Curr Biol, 2013, 23: 2151-2156

139 Sun Y, Ambrose JH, Haughey BS, Webster TD, Pierrie SN, Muñoz DF, Wellman EC, Cherian S, Lewis SM, Berchowitz LE, Copenhaver GP. Deep genome-wide measurement of meiotic gene conversion using tetrad analysis in Arabidopsis thaliana. PLoS Genet, 2012, 8: e1002968

140 Yang S, Yuan Y, Wang L, Li J, Wang W, Liu H, Chen JQ, Hurst LD, Tian D. Great majority of recombination events in Arabidopsis are gene conversion events. Proc Natl Acad Sci USA, 2012, 109: 20992-20997

141 Lu P, Han X, Qi J, Yang J, Wijeratne AJ, Li T, Ma H. Analysis of Arabidopsis genome-wide variations before and after meiosis and meiotic recombination by resequencing Landsberg erecta and all four products of a single meiosis. Genome Res, 2012, 22: 508-518

142 Qi J, Chen Y, Copenhaver GP, Ma H. Detection of genomic variations and DNA polymorphisms and impact on analysis of meiotic recombination and genetic mapping. Proc Natl Acad Sci USA, 2014, 111: 10007-10012

Open Access This article is distributed under the terms of the Creative Commons Attribution License which permits any use, distribution, and reproduction in any medium, provided the original author(s) and source are credited. 